\title{
Meneropong Wajah Studi Islam dalam Kacamata Filsafat: Sebuah Pendekatan Alternatif
}

\section{Toni Pransiska}

Program Doktoral

Universitas Islam Negeri Sunan kalijaga Yogyakarta, Indonesia

Email: tonyelnoory@ymail.com

\begin{abstract}
Abstrak
Islam sebagai penebar kedamaian dan kasih sayang (rahmatan li al-'ālamīn). Tentunya, memiliki beberapa konseptual, dogma, nilai-nilai kemanusiaan dan ajaran yang komprehensif. Hal inilah yang menyelamatkan manusia dari kebinasaan dan kehancuran. Oleh sebab itu, nilai-nilai dan ajaran islam harus selaras dengan norma-norma hidup manusia dan akomodatif terhadap kemajuan zaman kontemporer saat ini (shālih li kulli zamān wa makān). Islam dituntut untuk dapat memberikan sumbangsih pemecahan permasalahan (problem solving). Salah satu upaya tersebut adalah mengkaji islam dengan pendekatan filsafat (philosophy approach). Pendekatan ini memandang problematika keagamaan dari perspektif filsafati dan mencoba memberikan tawaran solusi dan pemecehan masalah dengan metode analitis-kritis. Dengan begitu, Islam sebagai agama yang berisi dogma dan ajaran, dapat dipahami dan dikaji secara mendalam, komprehensif dan mengungkap hikmah dibalik ritual dan ajarannya.
\end{abstract}

Kata Kunci: Studi Islam, Pendekatan Filosofis, Dogma

Kehadiran agama dewasa ini semakin dituntut agar ikut terlibat secara aktif dalam memecahkan berbagai masalah yang dihadapi umat manusia. (Anwar, 2009, hal. 71) Agama tidak boleh hanya sekedar menjadi lambang kesalehan atau berhenti sekedar disampaikan dalam khutbah, melainkan harus menunjukkan cara-cara yang paling efektif dalam memecahkan masalah (Nata, 2009, hal. 27).

Umat diharapkan dapat mengkaji berbagai pendekatan yang dapat digunakan dalam memahami agama (Islam). Pendekatan-pendekatan tersebut perlu dilakukan agar kehadiran agama secara fungsional dapat dirasakan oleh penganutnya. Sebaliknya tanpa mengetahui berbagai pendekatan tersebut, maka tidak mustahil agama menjadi sulit dipahami oleh masyarakat, tidak fungsional, 
Toni Pransiska

Meneropong Wajah Studi Islam dalam Kacamata Filsafat:

Sebuah Pendekatan Alternatif

kaku, dan akhirnya masyarakat mencari pemecahan masalah kepada selain agama. (Daradjat, 1996, hal. 37)

Berpikir secara filosofis dapat digunakan dalam memahami ajaran agama. Pendekatan filosofis yang demikian itu sebenarnya sudah banyak dilakukan oleh para ahli. Agar seseorang tidak terjebak pada pengamalan agama yang bersifat formalistic, yakni mengamalkan agama dengan susah payah tapi tidak memiliki makna apa-apa, kosong tanpa arti, maka Islam menyuruh penganutnya mempergunakan akal pikiran (rasio) dalam memahami ajaran agamanya. (Muhaimin, 2007, hal. 7)

Dalam tulisan ini penulis mencoba memahami dan menelaah Islam melalui pendekatan filosofis, sehingga Islam sebagai rahmatan li al- 'alamin dapat dipahami dengan baik dan mampu memberikan alternatif pemecahan masalah umat atau solusi dari kondisi problematis umat dan mampu menjawab tantangan dan tuntutan zaman modern dan era globalisasi sekarang ini.

\section{Pengertian Pendekatan Filosofis}

Istilah "filsafat" dalam bahasa Indonesia memiliki padanan kata falsafah (Arab), philosiphy (Inggris), philosophia (Latin), philosophie (Jerman, Belanda, Perancis). Semua istilah itu bersumber pada istilah Yunani philosophia. Istilah Yunani philein berarti "mencintai", sedangkan philos berarti "teman". Selanjutnya istilah shopos berarti "bijaksana", sedangkan sophia berarti "kebijaksanaan". (Ilmu, 2007, hal. 18)

Harun Nasution mengatakan bahwa kata 'filsafat' dalam istilah Indonesia berawal dari bahasa Arab, falsafa, bukan Inggris. karena, bahasa Arab lebih awal mempengaruhi bahasa Indonesia dibandingkan dengan bahasa Inggris. timbangan (wazan) dari falsafa adalah fa 'lala, fa'lalah dan fi'lal. Dengan demikian, menurut Harun Nasution, kata benda dari falsafa seharusnya falsafah dan filsaf. Menurutnya, dalam bahasa Indonesia banyak terpakai kata filsafat, padahal kata itu bukan berasal dari kata Arab, falsafah, dan bukan dari kata Inggris philosophy. (Nasution, Falsafat Agama, 2003, hal. 3) Harun Nasution mempertanyakan apakah kata 'fil' berasal dari bahasa Inggris dan 'safah' diambil dari kata Arab, sehingga terjadilah gabungan antara keduanya yang kemudian menimbulkan kata filsafat.

Pengertian filsafat secara terminologi sangat beragama, baik dalam ungkapan maupun titik tekannya. Seperti Plato (427-347 SM) misalnya, filsuf Yunani yang termashur, murid Socrates dan guru Aristoteles mengatakan bahwa filsafat itu tidak lain daripada pengetahuan tentang segala yang ada. Adapun 
menurut Aristoteles (384-322 SM) seorang filsuf terbesar, murid Plato dan guru Iskandar dari Macedonia berpendapat bahwa filsafat menyelidiki sebab dan asas segala benda. Karena itu, Aritoteles menamakan filsafat dengan "teologi" atau "filsafat pertama". Aritoteles sampai pada kesimpulan bahwa setiap gerak di alam digerakkan oleh yang lain. Karen itu, perlu menetapkan satu Penggerak Pertama yang menyebabkan gerak itu, sedangkan dirinya sendiri tidak bergerak. Penggerak yang pertama ini sama sekali terlepas dari materi; sebab kalau ia bermateri, maka ia juga mempunyai potensi untuk bergerak. Allah, demikian Aristoteles, sebagai penggerak pertama adalah Aktus Murni. (Bertens, 1981, hal. 155)

Sementara itu Al-Farabi mengatakan bahwa filsafat adalah pengetahuan tentang alam yang maujud dan bertujuan menyelidiki hakikat yang sebenarnya. (Ahmadi, 1988, hal. 8) Pengertian filsafat yang umunya digunakan adalah pendapat yang dikemukakan Sidi Gazalba. Menurutnya filsafat adalah berpikir secara mendalam, sistematik, radikal dan universal dalam rangka mencari kebenaran, inti, hikmah, atau hakikat mengenai segala sesuatu yang ada. (Gazalba, 1967, hal. 15) Sementara itu, Harun Nasution mengatakan bahwa filsafat adalah berfikir menurut tata tertib (logika) dengan bebas (tidak terikat pada tradisi, dogma, dan agama) dan sedalam-dalamnya, sehingga sampai ke dasar-dasar persoalan (Nasution, Falsafat Agama, 2003, hal. 3).

Dari sekian definisi tersebut terdapat persamaan yang cukup pokok dan sekaligus merupakan unsur-unsur dasar filsafat (Bakhtiar, 2007, hal. 9) Dengan demikian dapat diketahui bahwa filsafat pada intinya adalah upaya atau usaha untuk menjelaskan inti, hakikat, atau hikmah mengenai sesuatu yang berada dibalik objek formanya. Filsafat mencari sesuatu yang mendasar, asas, dan inti yang terdapat dibalik yang bersifat lahiriah.

Berpikir secara filosofis tersebut selanjutnya dapat digunakan dalam memahami ajaran agama, dengan maksud agar hikmah, hakikat atau inti dari ajaran agama dapat dimengerti dan dipahami secara seksama. Pendekatan filosofis yang demikian itu sebenarnya sudah banyak dilakukan oleh para ahli (Nata, 2009, hal. 43) Pendekatan filosofis yang dimaksudkan adalah melihat suatu permasalahan dari sudut tinjauan filsafat dan berusaha untuk menjawab dan memecahkan permasalahan itu dengan menggunakan metode analisis-spekulatif (Muhaimin, 2007, hal. 13).

Pendekatan filosofis biasanya mencoba menjawab pertanyaan esensial ini: Apakah agama itu? Pendekatan filosofis kemudian menjawabnya dalam dua cara. Pertama, penyelidikan mendalam seputar makna agama, dan apakah agama itu 
Toni Pransiska

Meneropong Wajah Studi Islam dalam Kacamata Filsafat:

Sebuah Pendekatan Alternatif

benar atau tidak. Kedua, pemeriksaan menyangkut makna agama bagi kehidupan manusia.

Melalui pendekatan filosofis ini, seseorang tidak akan terjebak pada pengalaman agama yang bersifat formalistik, yakni mengamalkan agama dengan susah payah tapi tidak memiliki makna apa-apa, kosong tanpa arti. Yang mereka dapatkan dari pengamalan agama tersebut hanyalah pengakuan formalistik, misalnya sudah haji, sudah menunaikan rukun islam yang kelima dan berhenti sampai di situ. Mereka tidak dapat merasakan nilai-nilai spiritual yang terkandung di dalamnya (Nata, 2009, hal. 45).

Manfaat yang bisa didapat ketika seseorang menggunakan pendekatan filosofis dalam kajian agamanya adalah sebagai berikut; (1) agar hikmah, hakikat dan inti dari ajaran agama dapat dimengerti dan dipahami secara seksama; (2) setiap individu dapat memberi makna terhadap segala sesuatu yang dijumpainya dan mengambil hikmah sehingga ketika melakukan ibadah atau apapun, ia tidak mengalami degradasi spiritual yang menimbulkan kebosanan; (3) membentuk pribadi yang selalu berpikir kritis (critical thought); (4) adanya kebebasan intelektual (intellectual freedom); dan (5) membentuk pribadi yang selalu toleran dan bijak dalam menyikapi sebuah problem kehidupan (Hazier Ika Silvia Marlina, 2017).

\section{Ajaran Islam Mendorong Berfilsafat}

Islam sebagai agama yang banyak menyuruh penganutnya mempergunakan akal pikiran sudah dapat dipastikan sangat memerlukan pendekatan filosofis dalam memahami ajaran agamanya. Namun demikian pendekatan seperti ini masih belum diterima secara merata terutama kaum tradisionalis-formalistis yang cenderung memahami agama terbatas pada ketepatan melaksanakan aturan-aturan formalistik dari pengamalan agama.

Agama Islam memberikan penghargaan yang tinggi terhadap akal, tidak sedikit ayat-ayat Al-Qur'an yang menganjurkan dan mendorong manusia supaya banyak berpikir dan menggunakan akalnya. Di dalam al-Qur'an dijumpai perkataan yang berakar dari kata 'aql (akal) sebanyak 49 kali, yang semuanya dalam bentuk kata kerja aktif, seperti 'aqalûh'; ta'qilûn; na'qil; ya'qilûnahâ; dan ya'qilûn (Muhaimin, 2007, hal. 306).

Harun Nasution menjelaskan bahwa kata 'aqala berarti mengikat dan menahan. Maka tali pengikat serban terkadang berwarna hitam dan terkadang berwarna emas, yang dipakai di Arab Saudi dan lainnya disebut iqâl (عقال); dan 
menahan orang di dalam penjara disebut i'taqala (اعتقل) dan tempat tahanan disebut mu'taqal (متقل) (Nasution, Akal dan Wahyu dalam Islam, 1986, hal. 6-7) Sementara menurut pemahaman Izutzu, kata ' $a q l$ di zaman Jahiliyah dipakai dalam arti kecerdasan praktis (practical intelegence) yang dalam istilah psikologi modern disebut kecakapan memecahkan masalah (problem-solving capacity). Orang berakal menurut pendapatnya adalah orang yang mempunyai kecakapan untuk menyelesaikan masalah, setiap kali ia dihadapkan dengan problema dan selanjutnya dapat melepaskan diri dari bahaya yang ia hadapi. Kebijaksanaan praktis serupa ini amat dihargai oleh orang Arab zaman Jahiliyah.

Aktivitas akal disebut berpikir. Berpikir merupakan ciri khas yang dimiliki oleh manusia sebagai mahluk yang paling tinggi derajatnya di muka bumi ini. Berpikir secara umum disebut sebagai suatu perkembangan konsep, idea dan sebagainya (Suriasumantri, 1981, hal. 52).

Kata-kata yang dipakai al-Qur'an untuk menggambarkan aktivitas berpikir bukan hanya 'aqala, tetapi juga kata-kata seperti nazhara (melihat secara abstrak, dalam arti berpikir dan merenungkan); misalnya QS. At-Thariq ayat 5-7 dan sebagainya; tadabbara (merenungkan kembali hal-hal yang telah dilalui), misalnya QS. Shad ayat 29 dan lain-lain; tafakkara (berpikir) seperti QS. Al-Anfal ayat 6869 dan lain-lain; faqiha (memahami, mengerti), seperti QS. Al-Isra' ayat 44; tadzakkara (mengingat, memperoleh peringatan, mendapat pelajaran, memperhatikan dan mempelajari), seperti QS. An-Nahl ayat 17, az-Zumar ayat 9 dan lain-lain; fahima (memahami) seperti dalam QS. Al-Anbiya' ayat 78-79 dan lain-lain (Nasution, 1986, hal. 39-44).

Selain itu di dalam al-Qur'an juga terdapat sebutan-sebutan yang memberi sifat berpikir bagi seorang muslim, yaitu ûlul albâb (orang-orang yang berpikir), seperti QS. Yusuf ayat 111; ûlu al-'ilm (orang-orang yang berilmu), seperti dalam QS Ali Imran ayat 18; ulul Abshar (orang yang mempunyai pandangan), seperti dalam QS an-Nur ayat 44; ulu al-nuhâi (orang bijaksana), seperti QS Thaha ayat 128.

Disamping itu, anjuran dan dorongan untuk berfilsafat dapat dipahami dari pengertian ayat itu sendiri. Kata ayat itu sendiri erat kaitannya dengan perbuatan berpikir. Arti asal dari kata ayat adalah tanda (sign). Sebagaimana diketahui bahwa tanda itu menunjukkan kepada sesuatu yang terletak dibelakang atau dibalik tanda itu (fenomenon). Baik secara filosofis maupun ilmiah, untuk mengetahui arti yang terletak dibelakangnya (Nasution, 1986, hal. 46-47) 


\section{Karakteristik Prinsipil Pendekatan Filosofis}

John Hick menyatakan bahwa pemikiran filosofis mengenai agama bukan merupakan cabang teologi atau studi-studi keagamaan, melainkan sebagai cabang filsafat. Dengan demikian filsafat agama merupakan suatu "aktivitas keteraturan kedua" (second order activity) yang menggunakan perangkat-perangkat filsafat bagi agama dan pemikiran keagamaan (Hick, 1983, hal. v). Pernyataan Hick memberikan suatu cara yang menarik kepada kita dalam membahas apa gambaran karakteristik pendekatan filosofis. Pada umumnya kita dapat menyatakan pendekatanpendekatan filosofis memiliki empat cabang yaitu (Connoly, 2009, hal. 170):

Pertama, Logika. Sebagai cabang filsafat, bahwa logika bersangkutan dengan kegiatan berpikir. Secara etimologi, logika berasal dari kata Yunani logos, yang berarti kata, nalar, teori atau uraian. Logika dapat didefinisikan sebagai ilmu, kecakapan atau alat untuk berpikir secara lurus. Dengan demikian yang menjadi objek material logika adalah pemikiran, sedangkan objek formalnya adalah kelurusan berpikir (Ilmu, 2007, hal. 32). Sementara itu Ahmad Saebani menjelaskan bahwa logika sebagai ilmu pengetahuan yang membicarakan asas-asas penentuan cara berpikir yang lurus, tepat, akurat, sehat dan kuat (Saebani, 2009, hal. 72-73).

Logika sendiri mempunyai tujuan untuk memperjelas isi atau komprehensi serta keluasan atau ekstensi suatu pengertian atau istilah dengan menggunakan definisi-definisi yang tajam (Kasmadi, 1990, hal. 45). Sedangkan fungsi logika adalah (1) membedakan ilmu yang satu dari yang lain apabila objeknya sama; dan (2) menjadi dasar ilmu pada umumnya dan falsafah pada khususnya.

Kedua, Metafisika (Connoly, 2009, hal. 173). Istilah metafisika berasal dari kata Yunani meta ta physika yang berarti sesuatu yang ada dibalik atau dibelakang benda-benda fisik. Metafisika dapat didefinisikan sebagai studi atau pemikiran tentang sifat yang terdalam (ultimate nature) dari kenyataan atau keberadaan (eksistensi) (Ilmu, 2007, hal. 31). Sementara menurut Hartono, metafisika kajian yang termasuk ke dalam teori tentang ada dan yang tidak ada, hakikat keberadaan suatu zat, hakikat pikiran dan kaitan antara pikiran dan zat (Kasmadi, 1990, hal. 13).

Ketiga, Epistemologi. Epistemologi juga disebut teori pengetahuan (theory of knowledge). Secara etimologi, istilah epistemologi berasal dari kata Yunani epsteme berarti pengetahuan dan logos berarti teori. Epistemologi dapat didefinisikan sebagai cabang filsafat yang mempelajari asal-mula, atau sumber, struktur, metode dan syahnya (validitas) pengetahuan (Ilmu, 2007, hal. 32). Harun Nasution mendefinisikan epistemologi sebagai ilmu yang membahas apa itu pengetahuan dan bagaimana cara memperoleh pengetahuan tersebut (Nasution, 
1986, hal. 7). Metodologi secara filsafati termasuk dalam apa yang dinamakan epistemologi. Metodologi merupakan suatu pengkajian dalam mempelajari peraturan-peraturan dalam metode tersebut.

Keempat, Etika. Etika sebagai cabang filsafat juga disebut filsafat moral (moral philosophy). Secara etimologi etika berasal dari kata Yunani ethos berarti watak (Ilmu, 2007, hal. 33). Sedangkan Peter Connolly menjelaskan bahwa secara harfiah etika berarti studi tentang "perilaku" atau studi dan penyelidikan tentang nilai-nilai yang dengannya kita hidup, yang mengatur cara kita hidup dengan lainnya, dalam satu komunitas lokal, komunitas nasional, maupun komunitas global internasional. Etika menitikberatkan perhatian pada pertanyaan-pertanyaan tentang kewajiban, keadilan, cinta, dan kebaikan (Connoly, 2009, hal. 175).

\section{Pola Pendekatan Filosofis dalam Studi Islam}

Menggunakan pendekatan filosofis dalam kajian Islam dapat dideskripsikan dalam dua pola, yaitu (Nata, 2009, hal. 43-44); Pertama, Upaya ilmiah yang dilakukan secara sistematis untuk mengetahui dan memahami serta membahas secara mendalam seluk beluk atau hal-hal yang berhubungan dengan agama Islam, baik ajaran, sejarah maupun praktek-praktek pelaksanaannya secara nyata dalam kehidupan sehari-hari, sepanjang sejarahnya dengan menggunakan paradigma dan metodologi disiplin filsafat. Kedua, Upaya ilmiah yang dilakukan secara sistematis untuk mengetahui dan memahami serta membahas nilai-nilai filosofis (hikmah) yang terkandung dalam doktrin-doktrin ajaran Islam yang bersumber pada AlQur'an dan As-Sunnah yang selanjutnya dilaksanakan dalam praktek-praktek keagamaan. Oleh karena itu, untuk menjelaskan pola yang pertama, ada baiknya jika dijelaskan terlebih dahulu metode yang dapat ditempuh dalam kajian Islam melalui pendekatan filosofis. Sebagai suatu metode, pengembangan suatu ilmu, dalam hal ini kajian Islam, memerlukan empat hal sebagai berikut:

1. Bahan. Bahan-bahan yang akan digunakan untuk pengembangan didiplin ilmu. Dalam hal ini dapat berupa bahan tertulis yaitu, Al-Qur'an dan As-Sunnahserta pendapat para ulama atau filosof. Dan bahan yang diambil dari pengalaman empirik dalam praktek keberagamaan.

2. Metode pencarian bahan. yakni untuk mencari bahan-bahan yang bersifat tertulis dapat dilakukan melalui studi kepustakaan dan studi lapangan yang masing-masing prosedurnya telah diatur sedemikian rupa.

3. Metode pembahasan. Dalam hal ini Muzayyin Arifin mengajukan alternatif metode analitis-sintetis, yaitu metode yang berdasarkan pendekatan rasional 
Toni Pransiska

Meneropong Wajah Studi Islam dalam Kacamata Filsafat:

Sebuah Pendekatan Alternatif

dan logis terhadap sasaran pemikiran secara induktif, deduktif, dan analisa ilmiah.

4. Pendekatan. Pendekatan biasanya diperlukan dalam analisa, dan berhubungan dengan teori-teori keilmuan tertentu yang akan dipilih untuk menjelaskan fenomena tertentu pula. Dalam hubungan ini pendekatan lebih merupakan pisau yang akan digunakan dalam analisa. Ia semacam paradigma (cara pandang) yang digunakan untuk menjelaskan suatu fenomena. Hal ini selanjutnya erat hubungannya dengan disiplin keilmuan.

Sedangkan dalam pola kedua, pendekatan filosofis dilakukan untuk mengurai nilai-nilai filosofis atau hikmah yang terkandung dalam doktrin-doktrin ajaran Islam yang terdapat dalam Al-Qur'an dan As-Sunnah, seperti hikmah dalam penerapan syariat Islam atau hikmah dalam perintah tentang shalat, puasa, haji, dan sebagainya. Pola ini banyak ditempuh oleh beberapa ulama, antara lain Imam AsSyatibi melalui karyanya: Al-Muwafaqatu fi Ushūl Al-Syarīati.

Pola pendekatan tersebut diharapkan agar seseorang tidak akan terjebak pada pengamalan agama yang bersifat formalistik, yakni mengamalkan agama dengan susah payah tapi tidak memiliki makna apa-apa, kosong tanpa arti. Yang mereka dapatkan dari pengamalan agama tersebut hanyalah pengakuan formalistik, misalnya sudah haji, sudah menunaikan rukun Islam yang kelima, dan berhenti sampai di situ. Mereka tidak dapat merasakan nilai-nilai spiritual yang terkandung di dalamnya. Namun demikian, pendekatan filosofis ini tidak berarti menafikan atau menyepelekan bentuk pengamalan agama yang bersifat formal. Filsafat mempelajari segi batin yang bersifat esoterik, sedangkan bentuk (forma) memfokuskan segi lahiriah yang bersifat eksoterik (Nata, 2009, hal. 45),

\section{Model Pendekatan Filosofis dalam Kajian Islam}

Jamali Sahrodi menyebutkan setidaknya ada tiga jenis atau model yang termasuk pendekatan filsafat modern (kontemporer) yang digunakan dalam kajian Islam, yaitu: pendekatan hermeneutika, pendekatan teologi-filosofis, dan pendekatan tafsir falsafi.

1. Pendekatan Hermeneutik

Kata hermeneutik berasal dari bahasa Yunani hermeneuein yang berarti menafsirkan, dan dari kata hermeneuein ini dapat ditarik kata benda hermenia yang berarti penafisran atau interprestasi dan hermeneutes yang berarti interpreter (penafsir). Kata ini sering diasosiasikan dengan nama salah seorang dewa Yunani, Hermes yang dianggap sebagai utusan para dewa bagi manusia. Hermes adalah 
utusan para dewa di langit untuk membawa pesan kepada manusia (Sumaryono, 1999, hal. 23).

Hermeneutika secara terminologis dapat didefinisikan sebagai tiga hal: 1) Mengungkapkan pikiran seseorang dalam kata-kata, menerjemahkan dan bertindak sebagai penafsir; 2) Usaha mengalihkan dari suatu bahasa asing yang maknanya gelap tidak diketahui ke dalam bahasa lain yang bisa dimengerti oleh si pembaca (reader); 3) Pemindahan ungkapan pikiran yang kurang jelas, diubah menjadi bentuk ungkapan yang lebih jelas (Faiz F. , 2007, hal. 19). Fungsi hermeneutika adalah untuk mengetahui makna dalam kata, kalimat dan teks. Hermeneutika juga berfungsi menemukan instruksi dari simbol. Menurut Josef Bleicherr, hermeneutika dapat dipetakan menjadi tiga bagian, yaitu (Sahrodi, 2008, hal. 18-19): 1) Hermeneutika sebagai metodologi; 2) Hermeneutika sebagai filsafat/filosofis; dan 3) Hermeneutika sebagai kritik.

Salah satu kajian penting hermeneutik adalah bagaimana merumuskan relasi yang pas antara nash (text), penulis atau pengarang (author), dan pembaca (reader) dalam dinamika pergumulan penafsiran/pemikiran nash termasuk dalam nash-nash keagamaan dalam Islam. Perlu disadari, semestinya kekuasaan (otoritas) atas nash adalah hanya mutlak menjadi hak Tuhan. Hanya Tuhan sajalah yang (author) yang tahu persis apa yang sebenarnya Dia kehendaki dan maui dalam firman-firman-Nya sebagaimana tertuang dalam nash. Manusia sebagai penafsir (reader), hanya mampu memosisikan dirinya sebagai penafsir atas nash yang diungkapkan Tuhan dengan segala kekurangan dan keterbatasannya. Dengan demikian, penafsiran yang paling relevan dan paling benar mestinya hanyalah keinginan dan kehendak si pengarang, dan bukan terletak di tangan penafsir (Syamsuddin, 2003, hal. 103).

Istilah hermeneutika dalam pengertian teori penafsiran kitab suci ini pertama kali dimunculkan oleh J.C. Dannhauer dalam bukunya Hermeneutica Sacra Siva Methodus Expondarum Sacrarum Litterarum. Istilah hermeneutika dalam hal ini dimaksudkan sebagai kegiatan memahami kitab-kitab suci yang dilakukan para agamawan. Kata hermeneutika dalam pengertian ini muncul pada abad 17-an, meskipun sebenarnya kegiatan penafsiran dan pembicaraan tentang teori-teori penafsiran, baik itu terhadap kitab suci, sastra maupun dalam bidang hukum, sudah berlangsung sejak lama. Dalam agama Yahudi misalnya, tafsir terhadap teks-teks Taurat dilakukan oleh para ahli kitab, yaitu mereka yang membaktikan hidupnya untuk mempelajari dan menafsirkan hukum-hukum agama yang dibawa oleh para Nabi. Berbeda dengan kaum Yahudi, awal tradisi Kristen dengan pengalaman akan Yesus yang dianggap wafat dan bangkit lagi, juga menerapkan tafsir pada teks-teks 
Perjanjian Lama, dimana tafsir tersebut bisa dikategorikan hermeneutika, karena Perjanjian Lama dipahami secara Kristiani dan hasilnya kemudian disebut Perjanjian Baru (Syamsuddin, 2003, hal. 20-21).

Pada perkembangan selanjutnya ketika memasuki zaman modern, munculah Friedrich Ernst Daniel Schleiermacher, seorang pendeta yang nantinya dianggap sebagai bapak hermeutika modern karena "melahirkan kembali" hermeneutika melalui konsep hermeneutikanya yang disebut sebagai Hermeneutika Romantik (Syamsuddin, 2003, hal. 25). Istilah hermeneutika sendiri dalam sejarah keilmuan Islam, khususnya tafsir Al-Qur'an klasik, memang tidak ditemukan. Istilah tersebut popular justru dalam masa kemunduran. Meski demikian, menurut Farid Esack, sebagaimana dikutip Fakhruddin Faiz, dalam bukunya Qur'an: Liberation and Pluralism, praktik hermeneutika sebenarnya telah dilakukan oleh umat Islam sejak lama, khususnya ketika menghadapi Al-Qur'an. Bukti dari hal itu adalah;

Pertama, Problematika Hermeneutik senantiasa dialami dan dikaji, meski tidak ditampilkan secara definitif. Hal ini terbukti dari kajian-kajian mengenai asbabun nuzul dan nasakh-mansukh. Kedua, Perbedaan antara komentar komentar yang aktual terhadap Al-Qur'an (tafsir) dengan aturan, teori atau metode penafsiran telah ada sejak mulai munculnya literatur-literatur tafsir yang disusun dalam bentuk ilmu tafsir. Ketiga, Tafsir tradisional itu selalu dimasukkan dalam kategori-kategori, misalnya tafsir syiah, tafsir mu'tazilah, tafsir hukum, tafsir filsafat, dan lain sebagainya. Hal itu menunjukan adanya kelompok-kelompok tertentu, ideologiideologi tertentu, periode-periode tertentu, maupun horison-horison tertentu dari tafsir.

Dalam dunia pemikiran Islam, Hassan Hanafi yang pertama kali memperkenalkan Hermeneutika dalam bukunya berjudul: Les Methods d'Exeges, Essai sur La Science de Fordements de la Comprehension, ilm Ushul Al-Fiqh (Muzairi, 2003, hal. 30). Selain Hassan Hanafi, di Mesir ada Muhammad Abduh dan Nasr Hamid Abu Zayd tokoh islam yang menggeluti kajian hermeneutika, di India, Ahmad Khan, Amir Ali dan Ghulam Ahmad Parves, yang berusaha melakukan demitologisasi konsep-konsep dalam Al- Qur'an yang dianggap bersifat mitologis, di Aljazair, muncul Mohammed Arkoun yang menggagas ide cara baca semiotik terhadap Al-Qur'an, kemudian Fazlurrahman yang merumuskan hermeneutika semantik terhadap Al-Qur'an, dan kemudian dikenal sebagai double movement (Faiz, 2005, hal. 14-15).

Intizar, Volume 23, Nomor 1, 2017 


\section{Pendekatan Teologis Filosofis}

Kajian keislaman dengan menggunakan pendekatan teologi-filosofis bermula dari kemunculan pemahaman rasional di kalangan mutakallimin (ahli kalam) di kalangan umat Islam yaitu Mazhab Mu'tazilah. Mu'tazilah menyodorkan konsepkonsep teologi (ilmu kalam) dengan berbasiskan metodologi dan epistemologi disiplin filsafat Yunani yang pada saat itu tengah berpenetrasi dalam perkembangan intelektual dunia Islam (masa pemerintahan Bani Abbas) akibat proyek penterjemahan ilteraturliteratur Yunani yang dilakukan para sarjana muslim pada kurun waktu tersebut. Kehadiran mazhab teologi rasional ini berupaya memberikan jawaban-jawaban dengan pendekatan filosofis atas doktrin-doktrin pokok Tauhid yang pada saat itu tengah menjadi materi-materi perdebatan dalam blantika pemikiran Islam.

Kemunculan gerakan Mu'tazilah merupakan tahap yang amat terpenting dalam sejarah perkembangan intelektual Islam. Meskipun bukan golongan rasionalis murni, namun jelas mereka adalah pelopor yang amat bersungguhsungguh untuk digiatkannya pemikiran tentang tentang ajaran-ajaran pokok Islam secara lebih sistematis. Sikap mereka yang rasionalistik dimulai dengan titik tolak bahwa akal mempunyai kedudukan yang sama dengan wahyu dalam memahami agama. Sikap ini adalah konsekwensi logis dari dambaan mereka kepada pemikiran sistematis.

Kebetulan pula pada masa-masa akhir kekuasaan Umayyah itu sudah terasa adanya gelombang pengaruh Hellenisme di kalangan umat Islam. Karena pembawa rasional mereka, kaum Mu'tazilah merupakan kelompok pemikir muslim yang dengan cukup antusias menyambut invasi filsafat itu. Meskipun terdapat berbagai kesenjangan untuk memberi sistem kepada faham Mu'tazilah tingkat awal itu, namun tesis-tesis mereka jelas merupakan sekumpulan dogma yang ditegakkan di atas prinsip-prinsip rasional tertentu. Karena berpikir rasional dan sistematis itu sesungguhnya tuntutan alami agama Islam, maka penalarannya, di bidang lain, juga menghasilkan pemikiran yang rasional dan sistematis pula, seperti di bidang hukum syari'ah yang dirintis oleh Imam Syafi'i, perumus pertama prinsip-prinsip jurisprudensi (Ushul Al-Fiqh).

Pada era pemikiran Islam kontemporer, kajian Islam dengan pendekatan teologi-filosofis banyak dilakukan oleh beberapa tokoh orientalis (outsider) seperti dilakukan oleh W. Montgomery Watt melalui karyanya, Free Will and Predestination in Early Islam (1948), Islamic Theology and Theology (1960), dan The Formative Period of Islamic Thought (1973). Sumber-sumber kajian kalam (teologi oleh para sarjana barat banyak memanfaatkan literatur teologi Islam klasik 
Toni Pransiska

Meneropong Wajah Studi Islam dalam Kacamata Filsafat:

Sebuah Pendekatan Alternatif

seperti karya-karya Al-Syahrastani seperti Al-Milal wa Al-Nihal, Al-Baghdadi, AlFarq Bayn Al-Firāq dan Al-Asy'āri, Maqālat Al-Islāmiyyin.

3. Pendekatan Tafsir Falsafi

Al-Dzahabi, sebagaimana dikutip Jamali Sahrodi, menjelaskan bahwa tafsir falsafi adalah penafsiran ayat-ayat Al-Qur'an berdasarkan pendekatan-pendekatan filosofis, baik yang berusaha untuk mengadakan sintesis dan sinkretisasi antara teori-teori filsafat dengan ayat-ayat Al-Qur'an maupun yang berusaha menolak teori-teori filsafat yang dianggap bertentangan dengan ayat-ayat Al-Qur'an. Timbulnya tafsir jenis ini tidak terlepas dari perkenalan umat Islam dengan filsafat Hellenisme yang kemudian merangsang mereka untuk menggelutinya kemudian menjadikannya sebagai alat untuk menganalisis ajaran-ajaran Islam, khususnya AlQur'an (Yusuf, 2012, hal. 163).

Tafsir falsafi juga diartikan sebagai suatu tafsir yang bercorak filsafat. Dalam menjelaskan makna suatu ayat, mufassir mengutip atau merujuk pendapat para filsuf. Persoalan yang diperbincangkan dalam suatu ayat dimaknai atau didefinisikan berdasarkan pandangan para ahli filsafat. Makna suatu ayat ditakwilkan sehingga sesuai dengan pandangan mereka (Sahrodi, 2008, hal. 113114).

Selain tiga model pendekatan filsafat dalam kajian Islam yang telah disebut di atas, Tasawuf Falsafi juga bisa disebut sebagai disiplin kajian berpendekatan filsafat. Tasawuf falsafi, atau biasa juga disebut tasawuf nazhari, merupakan tasawuf yang ajaran-ajarannya memadukan antara visi mistis dan visi rasional sebagai pengasasannya. Tasawuf falsafi menggunakan terminologi filosofis dalam pengungkapannya. Terminologi filosofis tersebut berasal dari bermacam-macam ajaran filsafat yang telah mempengaruhi para tokohnya (Solihin, 2008, hal. 67).

\section{Pendekatan Filsafat Sebagai Alternatif Memahami Islam: Sebuah Implementasi}

Agama Islam adalah agama fitrah sehingga pokok-pokok isi ajaran agama Islam tentunya sesuai dan cocok dengan fitrah manusia. disamping itu juga, pokokpokok isi ajaran agama Islam tersebut mempunyai daya adaptasi dan integrasi yang kuat terhadap sistem hidup dan lingkungan budaya yang dimasukinya dan akan berkembang bersamanya. Kalau sekarang ini tampak bahwa praktik dan pelaksanaan ajaran agama Islam tidak sesuai atau dikatakan ketinggalan zaman, maka perlu dipertanyakan; mengapa terjadi demikian? Yang jelas bahwa keadaan tersebut merupakan pertanda bahwa telah terjadi penyimpangan dalam penjabaran 
dan operasionalisasi pokok-pokok isi ajaran agama Islam, dan harus diluruskan kembali (Muhaimin, 2007, hal. 10). Hal ini merupakan salah satu tantangan bagi studi agama Islam. Salah satu alternatif pemecahan yang dapat dilakukan dan diupayakan dalam studi Islam adalah mengkaji dan memahami Islam melalui pendekatan filosofis.

Untuk membawa pendekatan filosofis dalam tataran aplikasi kita tidak bisa lepas dari pengertian pendekatan filosofis yang bersifat mendalam, radikal, sistematik dan universal. Karena sumber pengetahuan pendekatan filosofis adalah rasio, maka untuk melakukan kajian dengan pendekatan ini akal mempunyai peranan yang sangat signifikan (Muliadi). Dalam hal ini, penulis akan mencoba memaparkan contoh kajian keagamaan tentang puasa sebagai wadah kesucian dan tanggung jawab pribadi.

Puasa adalah sebutan yang telah umum, berasal dari bahasa Sanskerta upawasa. Orang Jawa biasa menyebutnya dengan pasa. Sejumlah suku atau masyarakat di Indonesia biasa menyebut puasa juga (Sismono, 2010, hal. 2). Menurut Al-Qurthubi, puasa ialah "bersikap pasif dari melakukan sesuatu". Dalam banyak pengertian, puasa diartikan pula "tidak bergerak sama sekali, tidak bertiup, tenang di tempatnya, tidak makan, tidak minum dan lain-lainnya, seperti yang berlaku pada binatang, angin, tumbuh-tumbuhan, dan manusia (al-Qurthubi, 1952, hal. 649).

Sementara itu shaum menurut terminologi yang lazim yakni seperti yang diungkapkan oleh Sayyid Sabiq dalam Fiqh as-Sunnah nya bahwa shiyâm adalah menahan diri dari segala sesuatu yang dapat membatalkan puasa mulai dari terbit fajar hingga terbenamnya matahari dan disertai dengan niat (Sabiq, 1997, hal. 487). Sedangkan definisi yang sedikit berbeda disebutkan oleh Taqiyuddin Abu Bakar dalam kitabnya Kifâyah al-Akhyâr bahwa shaum adalah menahan diri yang tertentu, oleh orang yang tertentu dalam waktu yang tertentu dan dengan syarat-syarat yang tertentu pula (al-Husaini, 2007, hal. 204).

Banyak hadist yang menyebutkan dan menjelaskan perihal keutamaan ibadah puasa. Sebuah hadist menuturkan tentang adanya firman Tuhan (dalam bentuk hadist Qudsi); "Semua amal seorang anak adam (manusia) adalah baginya kecuali puasa, sebab puasa itu adalah untuk-Ku dan Aku-lah yang akan memberinya balasannya" (al-Jurjawi, t.th, hal. 228). Sehubungan dengan hal ini, Nucholish Madjid menjelaskan bahwa salah satu hikmah ibadah puasa ialah sifatnya yang pribadi atau personal, bahkan merupakan rahasia antara seorang manusia dengan Tuhannya. Dan segi kerahasiaan itu merupakan letak dan sumber 
Toni Pransiska

Meneropong Wajah Studi Islam dalam Kacamata Filsafat:

Sebuah Pendekatan Alternatif

hikmahnya, yang kerahasiaan itu sendiri terkait erat dengan makna keikhlasan dan ketulusan. Antara puasa yang sejati dan yang palsu hanyalah bedanya, misalnya seteguk air yang diminum oleh seseorang ketika ia berada sendirian (Madjid, 2000, hal. 8).

Puasa benar-benar merupakan latihan dan ujian kesadaran akan adanya Tuhan yang Maha Hadir (Omnipresent), dan yang mutlak tidak pernah lengah sedikitpun dalam pengawasan-Nya terhadap segala tingkah laku hamba-hambaNya. Puasa adalah penghayatan nyata akan makna firman bahwa "Dia (Allah) itu bersama kamu dimanapun kamu berada, dan Allah itu maha mengawasi akan segala sesuatu yang kamu perbuat". Kepunyaan Allah-lah Timur dan Barat; maka kemanapun kamu menghadap, di sanalah wajah Allah”. dan lainnya.

Lebih lanjut Nurcholish Madjid menjelaskan bahwa kesadaran yang sedalam-dalamnya akan kemaha Hadiran (omnipresent) Tuhan inilah yang melandasi ketakwaan atau merupakan hakikat ketakwaan itu sendiri. Dan yang membimbing seseorang ke arah tingkah laku yang baik dan terpuji. Dengan begitu dapat diharapkan ia akan tampil sebagai pribadi yang berbudi pekerti luhur, berakhlak karimah (Madjid, 2000, hal. 9). Pada hakikatnya, puasa adalah suatu ibadah yang dimensi kerahasiaan atau keprivatan (privacy) yang amat kuat. Dari situ juga dapat ditarik pengertian bahwa puasa adalah yang pertama dan utama merupakan sarana pendidikan tanggung jawab pribadi. Ia bertujuan mendidik agar kita mendalami keinsyafan akan Allah yang selalu menyertai dan mengawal kita dalam setiap saat dan tempat.

Disamping itu juga, untuk lebih memperjelas aplikasi pendekatan filosofis dalam kajian Islam berdasarkan penjelasan dari berbagai ahli, maka akan dipaparkan contoh dari hadist Rasullullah SAW yang berkenan dengan larangan melukis, sebagai berikut:

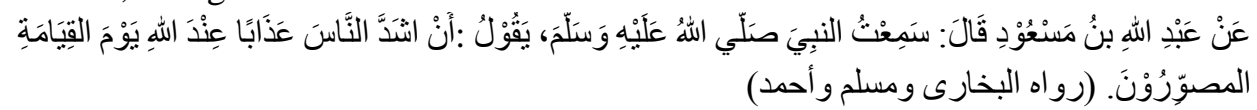

"Dari Abdillah bin Mas'ud, berkata: saya mendengarkan Nabi Muhammad SAW, berkata: sesungguhnya orang yang paling dahsyat siksanya di sisi Allah pada hari kiamat adalah para pelukis." (HR. Bukhari, Muslim dan Ahmad) (Muslim, 2010, hal. 323-324).

Secara tekstual hadist ini memberi pengertin adanya larangan melukis (makhluk yang bernyawa), bahkan para imam mazhab sepakat akan keharaman menggambar, memajangnya dan menjualnya. Kesimpulan seperti ini bisa dipahami, 
karena banyaknya riwayat mengenai masalah tersebut. Sebagaimana juga diriwayatkan pada hadist yang lain, bahwa para pelukis pada hari kiamat kelak dituntut untuk memberikan nyawa kepada apa yang pernah dilukisnya di dunia. Malaikat juga tidak akan masuk di rumah yang di dalamnya ada lukisannya (Thahir, 2003, hal. 19).

Kita perlu melihat kembali kondisi sosio-historis pada waktu hadist tersebut dituturkan Nabi. Hal tersebut berkaitan dengan kondisi kejiwaan masyarakat ketika itu, di mana mereka secara psikologis belum lama terlepas dari kepercayaan menyekutukan Allah SWT, yakni menyembah patung-patung berhala. Dalam kapasitasnya sebagai Rasulullah SAW, Nabi berusaha keras agar umat Islam terlepas dari kemusyrikan tersebut. Salah satu cara yang ditempuh dengan mengeluarkan larangan untuk memproduksi dan memajang lukisan atau berhala. Jika tidak dilakukan, maka mereka akan sulit melepaskan kepercayaan lama. Jadi hadist ini, secara psikis-antropologis sebenarnya disabdakan dalam kondisi masyarakat transisi dari kepercayaan animisme ke monoteisme, sehingga perlu adanya larangan keras terhadap praktik yang dapat menjerumuskan ke dalam kemusyrikan.

Persoalannya sekarang adalah bagaimana jika kondisi masyarakat sudah berubah, di mana masyarakat dengan perkembangan pemikirannya sudah berada pada tahap yang lebih baik atau dimungkinkan tidak lagi dikhawatirkan terjerumus ke dalam kemusyrikan. Apakah melukis patung masih tidak dibenarkan? Atau mungkin bisa saja, saat ini bukan lagi simbolik patung yang menyebabkan seseorang menjadi syirik, tetapi pemujaan terhadap figur-figur di bidang kesenian yang membuat penggemarnya gila dan histeris, misalnya seperti yang terjadi pada para fans berat Noah, Shoimah, Maroon 5, Adele, dan lain sebagainya.

Paparan diatas adalah bentuk penjelasan dan analisa singkat tentang prinsipprinsip temporal dan universalitas hadist Nabi sehingga terealisasi dalam konteks historis dan sosial yang berbeda. Salah satu perangkat metodologis dalam upaya memahami masa lampau dan kemudian merekonstruksi makna sebuah matan hadist dalam wacana kekinian dan kedisinian adalah pendekatan hermeneutik. Dalam pendekatan ini, sebuah matan hadist tidak mesti dipahami dalam bentuk pemahaman yang monolitik "seragam", karena sebuah hadist muncul dipengaruhi oleh berbagai segi seperti keadaan social, alam pikiran, budaya, bahasa pembacanya dan lain sebagainya.

Sehingga dapat dipahami, bahwa Islam sebagai agama yang banyak menyuruh penganutnya mempergunakan akal pikiran sudah dapat dipastikan sangat 
memerlukan pendekatan filosofis dalam memahami ajaran agamanya. Pendekatan filosofis adalah cara pandang atau paradigma yang bertujuan untuk menjelaskan inti, hakikat, atau hikmah mengenai sesuatu yang berada di balik objek formanya. Dengan kata lain, pendekatan filosofis adalah upaya sadar yang dilakukan untuk menjelaskan apa dibalik sesuatu yang nampak. Memahami ajaran Islam dengan pendekatan filosofis ini dimaksudkan agar seseorang melakukan pengamalan agama sekaligus mampu menyerap inti, hakikat atau hikmah dari apa yang diyakininya, bukan sebaliknya melakukan tanpa makna.

\section{Kesimpulan}

Mengkaji Islam tidak cukup dengan mempelajainya secara sepotongsepotong saja. Islam sebagai kajian ilmiah harus dipelajari dengan pendekatan atau metodologi yang tepat secara utuh dan komprehensi. Salah satu pendekatan yang dapat digunakan dalam mengkaji dan memahami Islam adalah pendekatan filosofis.

Memahami Islam dengan sudut pandang kefilsafatan dimaksudkan untuk dapat melihat suatu permasalahan yang ada dalam Islam dari sudut tinjauan filsafat dan berusaha untuk menjawab dan memecahkan permasalahan itu dengan menggunakan metode analisis-spekulatif. Sehingga pada gilirannya Islam sebagai sebuah agama yang berisi nilai-nilai, ajaran-ajaran, prinsip-prinsip, norma-norma hidup yang bersifat manusiawi dan universal dapat dipahami dengan baik dan benar.

Semangat untuk berpikir dan berfilsafat ternyata juga didukung oleh ajaran Islam itu sendiri. Hal ini tampak bagaimana ragam gaya bahasa al- al-Qur'an untuk menggambarkan aktivitas berpikir, seperti 'aqala, nazhara, tadabbara, tafakkara, dan lain sebagainya. Disamping itu juga, filsafat sebagai sebuah pendekatan memiliki karakteristik yang asasi dan prinsipil yakni bersifat logis, metafisis, epistemologis, dan etika.

Filsafat, dengan beragam karakteristik dasarnya yang inheren, sendiri berperan mengasah dan mempertajam penalaran kita, dan juga membongkar kejumudan pola pikir yang kita warisi begitu saja yang seakan turun dari langit, taken for granted, pula bagaikan mata kunci yang membuka hijab-hijab formalisme dan irasionalisme untuk menembus dan menangkap substansi persoalan. Idealitas filsafat inilah yang diharapkan juga meruhi upaya-upaya kajian Islam dengan menggunakan pendekatan filsafat agar produk pemikiran yang dilahirkan benarbenar menunjukan universalitas dan ke-rahmat-an Islam bagi umat, bagi manusia, dan bagi alam semesta. 


\section{Daftar Pustaka}

Ahmadi, A. (1988). Filsafat Islam. Semarang: Toha Putra.

al-Husaini, T. A. ( 2007). Kifāyah al-Akhyâr fî jal ghâyah al-Ikhtishâr. Surabaya: Bina Iman.

al-Jurjawi, A. (t.th). Ali Hikmah al-Tasyrī', wa Falsafatuhu 2 Jilid . Beirut: Dar alFikr.

al-Qurthubi, A. A. (1952). Tafsīr Jāmi’ al-Bayān. Kairo: Dar al-Kutub al-'Arab.

Anwar, R. (2009). Pengantar Studi Islam, Cet I. Bandung: CV. Pustaka Setia.

Bakhtiar, A. (2007). Filsafat Agama; Wisata Pemikiran dan Kepercayaan Manusia. Jakarta: RajaGrafindo Persada.

Bertens, K. (1981). Sejarah Filsafat Yunani. Yogyakarta: Kanisius.

Connoly, P. (2009). Aneka Pendekatan Studi Agama. Yogyakarta: Lkis.

Daradjat, Z. (1996). Perbandingan Agama. Jakarta: Bumi Aksara.

Faiz. (2005). FakhruddinHermeneutika Al-Qurani, tema-tema Kontroversial. Yoyakarta: elSAQ.

Faiz, F. (2007). Hermeutika Quran. Yogyakarta: Qalam.

Gazalba, S. (1967). Sistematika Filsafat, Jilid I, cet. II. Jakarta: Bulan Bintang.

Hick, J. (1983). Philosophy of Religion. Edisi 3. Englewood Cliffs N.J: PrenticeHal.

Hick, J. (1983). Philosophy of Religion. Edisi 3. Englewood Cliffs N.J: PrenticeHal.

Ilmu, T. D. (2007). Filsafat Ilmu. Yogyakarta: Liberty.

Kasmadi, H. (1990). Filsafat Ilmu. Semarang: IKIP Semarang Press.

Madjid, N. (2000). Dialog Ramadhan Bersama Cak Nur. Jakarta: Penerbit Paramadina.

Muhaimin. (2007). Kawasan dan Wawasan Studi Islam. Jakarta: Kencana.

Muliadi, E. (n.d.). Pendekatan Filosofis dalam Studi Islam. Retrieved Februari 27 , 2017, from http://erlanmuliadi.blogspot.co.id: http://erlanmuliadi.blogspot.com/2011/04/pendekatan-filosofis-dalamstudi-islam.html

Muslim, I. (2010). Shahih Muslim. Cairo: Dār al-Hadits.

Muzairi. (2003). Hermeneutika dalam Pemikiran Islam dalam Hermeneutika AlQur'an Mazhab Yogya. Bandung: Pustaka Islamika.

Nasution, H. (1986). Akal dan Wahyu dalam Islam. Jakarta: UI Press.

Nasution, H. (1986). Akal dan Wahyu dalam Islam. Jakarta: UI Press.

Nasution, H. (2003). Falsafat Agama. Jakarta: Bulan Bintang. 
Nata, A. (2009). Metodologi Studi Islam. Jakarta: Rajawali Pers.

Sabiq, S. (1997). Fiqh as-Sunnah. Beirut: Dar al-Fath al-I'lam al-'Araby.

Saebani, B. A. (2009). Filsafat Ilmu; Kontemplasi Filosofis tentang Seluk-beluk, Sumber dan Tujuan Ilmu Pengetahuan. Bandung: Pustaka Setia.

Sahrodi, J. (2008). , Metodologi Studi Islam,. Bandung: Pustaka Setia.

Sismono, H. (2010). Puasa pada Umat-umat Dulu dan Sekarang. Jakarta: Republika.

Solihin. (2008). Ilmu Tasawuf. Bandung: Pustaka Setia.

Sumaryono. (1999). Hermeneutika: Sebuah Metode Filsafat. Yogyakarta: Kanisius. Suriasumantri, J. S. (1981). Ilmu dalam Perspektif. Jakarta: PT. Gramedia.

Syamsuddin, S. (2003). Hermeneutika Al-Qur'an. Yogyakarta: Islamika.

Thahir, L. S. (2003). Studi Islam Interdisipliner, Aplikasi Pendekatan Filsafat, Sosiologi dan Sejarah. Yogyakarta: Penerbit Qalam.

Yusuf, K. M. (2012). Studi Al-Qur'an. Jakarta: Amzah. 